\title{
Efektivitas Media Huruf Bergambar Terhadap Kemampuan Menulis Permulaan Bagi Siswa Tunagrahita Ringan
}

\author{
Riska Ayu ${ }^{1}$ \\ ${ }^{1}$ Universitas Negeri Malang \\ Email: ${ }^{1}$ riskaayu_setyawardani@yahoo.com
}

\section{Tersedia Online di \\ http://www.jurnal.unublitar.ac.id/ index.php/briliant}

\begin{tabular}{l}
\hline Sejarah Artikel \\
\hline Diterima pada 2 November 2017 \\
Disetuji pada 2 November 2017 \\
Dipublikasikan pada 13 \\
November 2017 Hal. $448-458$ \\
\hline
\end{tabular}

\section{Kata Kunci:}

huruf bergambar, menulis permulaan, tunagrahita ringan,

\section{DOI:}

http://dx.doi.org/10.28926/briliant .v2i4.110

\begin{abstract}
Abstrak: Tujuan penelitian ini adalah (1) untuk mengetahui kemampuan menulis permulaan siswa tunagrahita ringan kelas I SDLB BC Kepanjen Kabupaten Malang sebelum diberikannya perlakuan, (2) untuk mengetahui kemampuan menulis permulaan siswa tunagrahita ringan kelas I SDLB BC Kepanjen Kabupaten Malang sesudah penggunaan media huruf bergambar, (3) untuk mengetahui efektivitas media huruf bergambar terhadap kemampuan emnulis permulaan siswa tunagrahita ringan kelas I SDLB BC Kepanjen Kabupaten Malang. Penelitian ini menggunakan metode penelitian eksperimen dengan desain One Group Times Series Desain. Hasil penelitian menunjukkan ada pengaruh media huruf bergambar terhadap kemampuan menulis permulaan siswa tunagrahita ringan kelas I SDLB BC Kepanjen Kabupaten Malang.
\end{abstract}

Anak tunagrahita merupakan bagian dari anak berkebutuhan khusus yang membutuhkan pendidikan. Pendidikan merupakan faktor penting dalam mencapai tujuan pembangunan nasional yaitu mencerdaskan kehidupan bangsa dan meningkatkan kualitas manusia dalam mewujudkan masyarakat yang adil dan makmur. Untuk mencapai tujuan tersebut setiap warga negara diberikan hak yang sama untuk mendapatkan pendidikan, tak terkecuali bagi anak berkebutuhan khusus termasuk anak tunagrahita. Pemerintah menjamin hak setiap warga negara untuk mendapatkan pendidikan sebagaimana yang tercantum dalam undangundang sistem pendidikan No. 20 Tahun 2003 pasal 31 setiap warga negara berhak mendapat pendidikan dan pengajaran, termasuk anak-anak yang berkebutuhan khusus, sesuai dengan karektiristiknya masing-masing. Hal ini sesuai dengan Undang-Undang nomor 20 tahun 2003 pasal 5 ayat 2 : Warga negara yang memiliki kelainan fisik, emosional, mental, intelektual dan/atau sosial berhak memperoleh pendidikan khusus.

Pendidikan anak berkebutuhan khusus salah satunya adalah pendidikan anak tunagrahita yang disebut juga dengan anak yang mengalami keterbelakangan mental. Dalam hal ini tujuan pendidikan anak tunagrahita sama dengan tujuan pendidikan anak berkebutuhan khusus lainnya yaitu supaya mendapatkan

pendidikan dan kehidupan yang layak baik secara lahir maupun batin. Pendidikan anak berkebutuhan khusus harus disesuaikan dengan jenis dan karakteristik pada masing-masing anak. Sehingga tujuan pendidikan dapat tercapai dengan baik. Anak tunagrahita memiliki kesulitan dalam membaca, menulis, berhitung. 
Dalam Pembelajaran Bahasa Indonesia mencakup empat (4) keterampilan berbahasa, yakni: mendengar, berbicara, membaca, dan menulis. Salah satu keterampilan berbahasa yang cukup kompleks adalah menulis. Menulis merupakan kegiatan yang paling komplek untuk dipelajari dan diajarkan (Farris, 1993).

Standar kompetensi bidang studi Bahasa Indonesia kelas 1 semester 1 menyebutkan bahwa aspek menulis permulaan meliputi menjiplak, menebalkan, mencontoh, melengkapi, dan menyalin. Kompetensi dasar yang seharusnya dikuasai adalah: (1) Menjiplak berbagai bentuk gambar, lingkaran, dan bentuk huruf; (2) Menebalkan berbagai bentuk gambar, lingkaran, dan bentuk huruf; (3) Mencontoh huruf, kata, atau kalimat sederhana dari buku atau papan tulis dengan benar; (4) Melengkapi kalimat yang belum selesai berdasarkan gambar; dan (5) Menyalin puisi anak sederhana dengan huruf lepas.

Keterampilan menulis sebagai salah satu keterampilan berbahasa merupakan hal yang sangat penting dan perlu mendapat perhatian khusus. Melalui menulis, manusia dapat mengenali kemampuan dan potensi yang ada pada dirinya dalam kegiatan menulis, tulisan yang baik dan jelas mudah di baca dan di pahami dalam pemakaian huruf serta jelas maksudnya. Huruf merupakan lambang bahasa yang di gunakan sebagai alat komunikasi secara tulisan bagi manusia. Maka dari itu, menulis bagi anak didik di sekolah bagi guru merupakan salah satu tujuan utama dari proses pembelajaran, termasuk untuk anak tunagrahita ringan.

Berdasarkan penelitian pada tanggal 7-8 April 2017, peneliti mengamati kegiatan KBM siswa tunagrahita ringan kelas 1 di SDLB BC Kepanjen Kab Malang dengan mata pelajaran Bahasa Indonesia yang dibawakan oleh guru kelas. Siswa dalam kelas masih mengalami kesulitan dalam menulis permulaan dikarenakan guru mangajar siswa tunagrahita untuk menulis permulaan dengan model menyalin tulisan dari papan tulis dan tidak adanya media. Maka dari itu peneliti membuat media huruf bergambar untuk siswa tunagrahita ringan agar proses KBM berjalan dengan baik.

Media merupakan alat yang digunakan di dalam proses KBM untuk menarik perhatian siswa. Tujuan dari media huruf bergambar yaitu untuk menarik perhatian siswa tunagrahita ringan dalam menulis permulaan, untuk memperjelas penyampaian pesan, selain itu agar siswa tunagrahita tidak memiliki rasa bosan saat proses belajar menulis permulaan.

Untuk mengatasi masalah kemampuan menulis permulaan siswa guru dituntut untuk lebih memahami dan mengembangkan berbagai metode di media kartu huruf serta keterampilan dalam proses pembelajaran agar dapat membangkitkan minat dan motivasi belajar siswa. Salah satu cara yang dapat ditempuh ke arah tersebut adalah penggunaan media, yang jika diterapkan dengan benar akan sangat mempengaruhi minat dan kemampuan siswa tersebut.

Berdasarkan uraian di atas diketahui banyak anak tunagrahita kelas 1 SDLB masih mengalami kesulitan dalam menulis permulaan, penulis merasa perlu adanya penelitian untuk menguji efektivitas media huruf bergambar terhadap kemampuan menulis permulaan. Maka tujuan penelitian ini adalah (1) Mengetahui kemampuan menulis permulaan pada siswa Tunagrahita ringan kelas 1 SDLB BC Kepanjen Kabupaten Malang sebelum menggunakan media huruf bergambar. (2) Mengetahui kemampuan menulis permulaan pada siswa Tunagrahita ringan kelas 1 SDLB BC Kepanjen Kabupaten Malang setelah diberi 
media huruf bergambar. (3) Mengetahui efektivitas media huruf bergambar terhadap menulis permulaan pada siswa Tunagrahita ringan kelas 1 SDLB BC Kepanjen Kabupaten Malang.

\section{METODE}

Penelitian ini termasuk penelitian kuantitatif, karena data penelitian berupa angka-angka dan analisis menggunakan statistik. Metode yang digunakan adalah metode eksperimen. Menurut Sugiyono (2015:107) penelitian eksperimen adalah metode penelitian yang digunakan untuk mencari pengaruh perlakuan tertentu terhadap yang lain dalam kondisi yang terkendalikan. Metode eksperimen yang digunakan dalam penelitian ini bertujuan untuk mengetahui keefektifan media huruf bergambar yang akan diberikan kepada subyek secara berulang-ulang pada waktu tertentu, dalam rangka meningkatkan menulis permulaan pada siswa tunagrahita ringan kelas I SDLB BC Kepanjen Kabupaten Malang. Sampel yang digunakan peneliti ini adalah 5 siswa tunagrahita ringan kelas I di SDLB BC Kepanjen Malang yang terdiri dari 1 perempuan dan 4 lakilaki. Validitas dalam penelitian ini adalah validitas isi dengan teknik penilaian ahli (judgement). Validasi isi dalam penelitian ini adalah berisi validasi ahli materi dan ahli media. Validator ahli materi pada penelitian ini selaku guru kelas 1 SDLB BC Kepanjen Kabupaten Malang. Sedangkan yang menjadi validator ahli media pada penelitian ini selaku dosen FIP (TEP) UM. Validasi dalam penelitian ini menggunakan instrumen berupa cek list.Untuk mengetahui efektif-tidaknya implementasi RPP dan media dalam praktik pembelajaran. Analisis data yang digunakan adalah analisis data deskriptif dan uji $\mathrm{T}$.

\section{HASIL}

\section{Data Kemampuan Menulis Permulaan Siswa Sebelum Menggunakan Media Huruf Bergambar (Pre-Test)}

Data kemampuan awal siswa merupakan data yang diperoleh dari hasil test sebelum diberikannya perlakuan (pre-test). Kagiatan pre test ini dilakukan sebanyak 4 kali. Data ini di ambil pada hari senin sampai kamis tanggal $10-13$ April 2017. Soal pre-test berupa soal untuk menulis permulaan anak tunagrahita. Disini peneliti hanya memberikan lembar kerja yang berupa menebali tulisan untuk siswa tunagrahita pada saat pre-test diberikan. Kegiatan pre-test hanya dilakukan dalam 1 kelas sebanyak 5 anak yaitu kelas 1 tunagrahita ringan SDLB BC Kepanjen Kabupaten Malang. Berikut ini adalah data hasil soal pre-test tentang menulis permulaan sebelum diberikannya perlakuan dengan menggunakan media huruf bergambar. Adapun hasil nilai dari pre-test menulis adalah sebagai berikut:

Tabel 1 Hasil Nilai Pre-Test

\begin{tabular}{|c|c|c|c|c|c|c|c|c|}
\hline \multirow[t]{2}{*}{ No } & \multirow[t]{2}{*}{ Nama } & \multicolumn{4}{|c|}{ Nilai Pre-Test } & \multirow{2}{*}{$\begin{array}{c}\text { Jum } \\
\text { lah }\end{array}$} & \multirow[t]{2}{*}{ Rata-rata } & \multirow{2}{*}{$\begin{array}{l}\text { Kriteri } \\
\quad \mathbf{a}\end{array}$} \\
\hline & & I & II & III & IV & & & \\
\hline 1. & Ferdi & 35 & 40 & 40 & 45 & 160 & 40 & Rendah \\
\hline 2. & Fadhil & 35 & 35 & 35 & 40 & 145 & 36,25 & $\begin{array}{l}\text { Sangat } \\
\text { Rendah }\end{array}$ \\
\hline 3. & Hani & 40 & 35 & 35 & 40 & 150 & 37,50 & Sangat \\
\hline
\end{tabular}




\begin{tabular}{|l|l|l|l|l|l|l|l|l|}
\hline & & & & & & & & Rendah \\
\hline 4. & Marik & 60 & 40 & 40 & 40 & 180 & 45 & Rendah \\
\hline 5. & Rizal & 40 & 35 & 35 & 35 & 145 & 36,25 & $\begin{array}{l}\text { Sangat } \\
\text { Rendah }\end{array}$ \\
\hline & \multicolumn{7}{|c|}{ Jumlah } \\
\hline
\end{tabular}

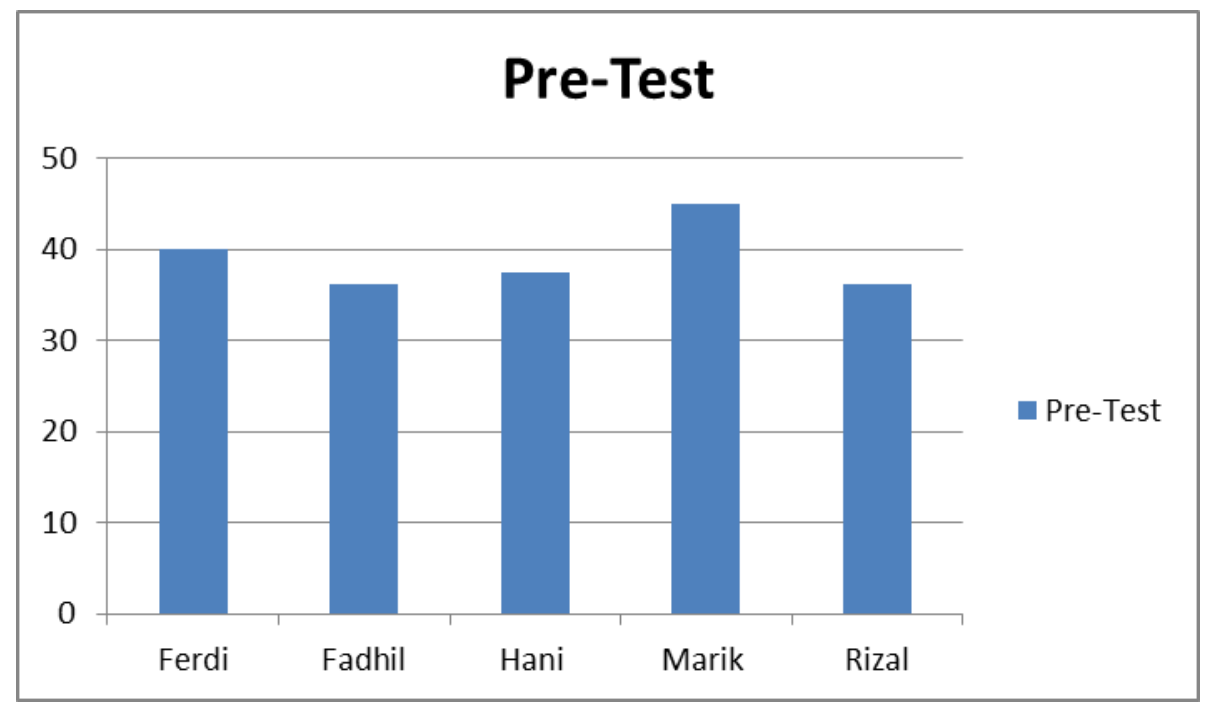

Diagram 2 Diagram nilai Pre-test

Berdasarkan data dari tabel diatas, dapat diketahui bahwa hasil pre-test kemampuan menulis permulaan siswa tunagrahita kelas 1 SDLB BC Kepanjen Kabupaten Malang diperoleh nilai rata-rata 39 dalam kategori sangat rendah. Kemampuan siswa dapat dilihat pada tabel berikut.

Tabel 2 Distribusi frekuensi hasil pretest

\begin{tabular}{|l|c|c|l|}
\hline \multicolumn{1}{|c|}{ Rentang nilai } & Frekuensi & Presentase & \multicolumn{1}{c|}{ Kategori } \\
\hline $80-100$ & - & - & Sangat baik \\
\hline $66-79$ & - & - & Baik \\
\hline $56-65$ & - & - & Cukup \\
\hline $40-55$ & 2 & $40 \%$ & Rendah \\
\hline $30-39$ & 3 & $60 \%$ & Sangat rendah \\
\hline Jumlah & 5 & 100 & \\
\hline
\end{tabular}

Berdasarkan tabel 2 dapat diketahui bahwa hasil pretest yaitu 2 siswa dengan presentase $40 \%$ berada pada kategori rendah, dan 3 siswa dengan presentase $60 \%$ berada pada kategori sangat rendah.

\section{Data Kemampuan Menulis Permulaan Siswa Sesudah Menggunakan Media Huruf Bergambar (Post-Test)}

Data kemampuan akhir siswa diperoleh dari hasil tes yang dilakukan setelah adanya perlakuan atau post test. Tujuan dari post test adalah untuk mengetahui peningkatan nilai dan pengaruh pemberian media huruf bergambar yang telah diaksanakan. Pada hari Selasa - Jumat tanggal 25 - 28 April 2017 peneliti melakukan pengukuran pemahaman siswa setelah diberikannya perlakuan 
dan untuk melihat efektifitas media huruf bergambar terhadap menulis permulaan siswa tunagrahita ringan kelas 1 SDLB BC Kepanjen Kabupaten Malang. Post test ini dilakukan sebanyak 4 kali dengan tujuan untuk mengetahui tingkat kestabilan.

Tabel 3 Hasil Nilai Post-Test

\begin{tabular}{|c|c|c|c|c|c|c|c|c|}
\hline \multirow[t]{2}{*}{ No } & \multirow[t]{2}{*}{ Nama } & \multicolumn{4}{|c|}{ Nilai Pre-Test } & \multirow[t]{2}{*}{ Jumlah } & \multirow[t]{2}{*}{ Rata-rata } & \multirow[t]{2}{*}{ Kriteria } \\
\hline & & I & II & III & IV & & & \\
\hline 1. & Ferdi & 75 & 80 & 80 & 85 & 320 & 80 & $\begin{array}{l}\text { Sangat } \\
\text { Tinggi }\end{array}$ \\
\hline 2. & Fadhil & 55 & 50 & 60 & 80 & 245 & 61,25 & Cukup \\
\hline 3. & Hani & 65 & 60 & 60 & 80 & 265 & 66,25 & Tinggi \\
\hline 4. & Marik & 90 & 80 & 85 & 100 & 355 & 88,75 & $\begin{array}{l}\text { Sangat } \\
\text { Tinggi }\end{array}$ \\
\hline 5. & Rizal & 55 & 75 & 60 & 80 & 270 & 67,5 & Tinggi \\
\hline & Jumlah & & & & & & $363,75: 5$ & 72,75 \\
\hline
\end{tabular}

Berdasarkan data dari tabel diatas, dapat diketahui bahwa hasil post-test kemampuan menulis permulaan siswa tunagrahita kelas 1 SDLB BC Kepanjen Kabupaten Malang diperoleh nilai rata-rata 72,75 dalam kategori baik. Kemampuan siswa dapat dilihat pada tabel berikut.

Tabel 4 Distribusi frekuensi hasil posttest

\begin{tabular}{|l|l|l|l|}
\hline Rentang nilai & Frekuensi & Presentase & Kategori \\
\hline $80-100$ & 2 & $40 \%$ & Sangat baik \\
\hline $66-79$ & 2 & $40 \%$ & Baik \\
\hline $56-65$ & 1 & $20 \%$ & Cukup \\
\hline $40-55$ & - & & Rendah \\
\hline $30-39$ & - & & Sangat rendah \\
\hline Jumlah & 5 & $100 \%$ & \\
\hline
\end{tabular}

Berdasarkan tabel 4 dapat diketahui bahwa hasil posttest yaitu 2 siswa dengan presentase $40 \%$ berada pada kategori sangat baik, 2 siswa dengan presentase $40 \%$ berada pada kategori baik, dan 1 siswa dengan presentase $20 \%$ berada pada kategori cukup.

\section{Uji Hipotesis}

Berdasarkan nilai pretest dan posttest yang tertera di atas, dapat diketahui hasil nilai keduanya untuk mengji hipotesis yaitu ada atau tidaknya pengaruh dari pemberian treatment atau perlakuan. Sebelum melakukan uji t, peneliti melakukan uji normalitas terlebih dahulu. Karena salah satu syarat uji t adalah distribusi data harus normal. Berikut ini hasil uji normalitas dengan bantuan SPSS 20 for windows.

Tabel 5 Uji Normalitas 


\begin{tabular}{|l|l|l|l|l|l|l|}
\hline & \multicolumn{3}{|l|}{ Kolmogorov-Smirnov $^{\mathrm{a}}$} & \multicolumn{3}{l|}{ Shapiro-Wilk } \\
\cline { 2 - 7 } & Statistic & df & Sig. & Statistic & df & Sig. \\
\hline pre_test & .258 & 5 & $.200^{*}$ & .831 & 5 & .141 \\
post_test & 279 & 5 & $.200^{*}$ & .913 & 5 & .488 \\
\hline
\end{tabular}

a. Lilliefors Significance Correction

*. This is a lower bound of the true significance.

Berdasarkan tabel 5 diperoleh 2 data yaitu data kolmogrov-smirnov dan data Shapiro-wilk. Kolmogorov-smirnv digunakan untuk sampel $>50$ sedangkan untuk Shapiro-walk digunakan untuk sampel $<50$. Karena dalam penelitian ini sampel digunakan sejumlah 5 siswa tunagrahita ringan kelas 1 SDLB BC Kepanjen Kabupaten Malang maka menggunakan Shapiro-wilk. Dari tabel diatas diperoleh nilai Sig. pre-test sebesar 0,141 > 0,05 dan Sig. posttest sebesar 0,488 > 0,05. Jadi dapat disimpulkan 2 data yaitu data pre-test dan data posttest berdistribusi normal. Setelah diketahui data berdistribusi normal maka peneliti dapat menggunakan uji $t$ dengan bantuan SPSS 20 for windows.

Tabel 6 Uji T Berpasangan (Paired Sample t-Test)

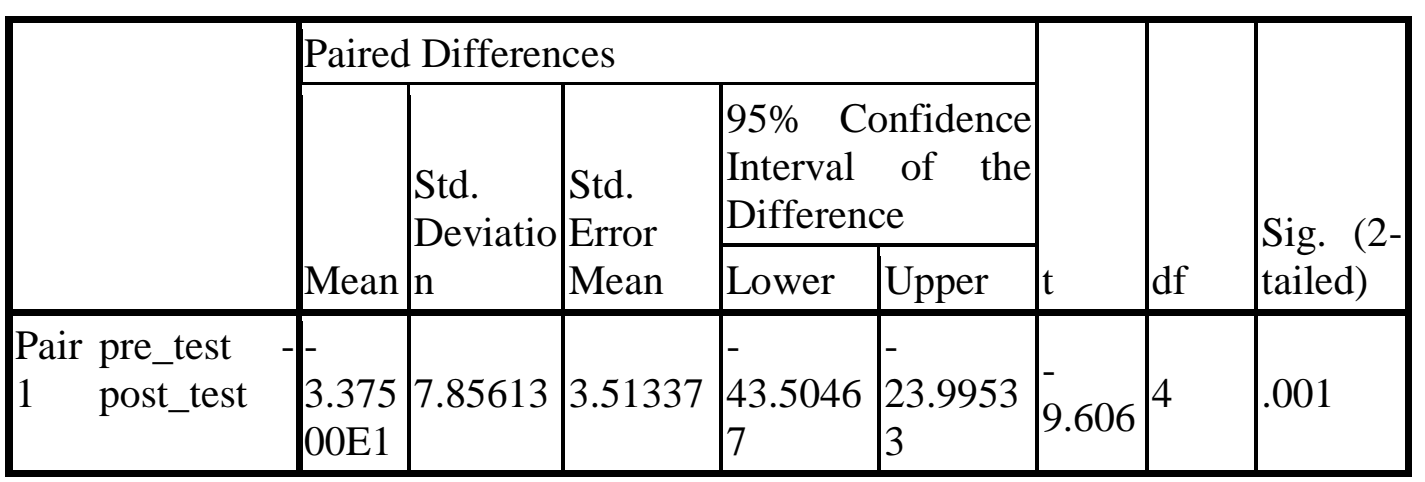

Berdasarkan hasil perhitungan uji t dengan bantuan program aplikasi SPSS diperoleh nilai sig 2 tailed sebesar 0,01 . Nilai sig 2 tailed $0,01<0,05$ jadi dapat disimpulkan ada pengaruh media huruf bergambar terhadap kemampuan siswa tunagrahita ringan kelas 1 SDLB BC Kepanjen Kabupaten Malang.

\section{PEMBAHASAN}

\section{Kemampuan menulis permulaan siswa tunagrahita ringan sebelum menggunakan media huruf bergambar.}

Berdasarkan analisis pretest dapat diketahui bahwa kemampuan menulis permulaan siswa sebelum diberikan perlakuan (treatment) sebanyak 2 siswa dengan presentase $40 \%$ berada pada kategori rendah, dan 3 siswa dengan presentase $60 \%$ berada pada kategori sangat rendah. Nilai rata-rata pretest siswa diperoleh nilai rata-rata 39 artinya kemampuan menulis permulaan siswa memiliki kategori rendah. 
Pada saat pemberian pretest terlihat banyak hasil menulis permulaan siswa yang tidak sesuai dengan soal. Siswa juga belum mengetahui huruf apa yang ada dihadapannya saat itu. Selain itu disini siswa tunagrahita ringan belum bisa menulis permulaan. Siswa belum bisa mengikuti gambar pola yang sudah

disediakan. Selain itu siswa masih dapat menggoreskan pensilnya di luar pola yang ada.

Berdasarkan hasil pre-test sebelum diberikannya perlakuan dengan media huruf bergambar kemampuan siswa dalam menulis permulaan dapat dikatakan sangat rendah. Hal ini terlihat dari nilai rata-rata siswa tunagrahita ringan kelas 1 SDLB BC Kepanjen Kabupaten Malang kurang dari 50.

Menulis merupakan suatu proses yang sangat kompleks karena kemampuan menulis merupakan integrasi dari berbagai kemampuan, yaitu kemampuan motorik halus, persepsi visual-motorik, visual memori, memori auditori, perhatian, konsentrasi, daya ingat, dan pemahaman yang dipengaruhi oleh kemampuan inteligensi seseorang. Menulis adalah proses yang komplek, yang mengintegrasikan kemampuan visual-spasial, motor, dan konseptual. Kemampuan menulis anak tidak akan berkembang apabila salah satu dari ketiga kemampuan tersebut tidak berkembang (Mercer \& Mercer, 1989).

Menurut Chori RGP, Asep A S, Yosfan A (2013:645) "Keterampilan menulis sebagai salah satu keterampilan berbahasa merupakan hal yang sangat penting dan perlu mendapat perhatian khusus. Melalui menulis, manusia dapat mengenali kemampuan dan potensi yang ada pada dirinya dalam kegiatan menulis, tulisan yang baik dan jelas mudah di baca dan di pahami dalam pemakaian huruf serta jelas maksudnya". Huruf merupakan lambang bahasa yang di gunakan sebagai alat komunikasi secara tulisan bagi manusia. Dalam menulis dibutuhkan kemampuan membedakan berbagai bentuk huruf, kemampuan dalam menentukan tanda baca, menggunakan huruf kapital dan huruf kecil, kemampuan dalam mengoordinasikan gerakan visual motorik pada waktu menulis, kemampuan mengekspresikan pikiran, dan perasaan dalam bentuk tulisan (Jamaris, 2009). Rendahnya inteligensi dan gangguan motorik yang dialami oleh anak tunagrahita memberi dampak yang amat berarti dalam mengeks-presikan pikiran dan perasaan melalui tulisan. Kesulitan dalam mengekspresikan pikiran dan perasaan tersebut berpengaruh terhadap pembentukan kognisi anak tunagrahita.

Berdasarkan kondisi siswa disekolah dalam menulis permulaan siswa tunagrahita mengalami kesulitan dalam belajar menulis dengan tangan atau menulis permulaan. Kesulitan menulis yang dialami oleh anak tunagrahita tersebut pada dasarnya disebabkan oleh rendahnya inteligensi. Rendahnya kemampuan intelegensi dan kelemahan adaptasi perilaku pada anak dengan kelainan tunagrahita berdampak kepada kesulitan dalam belajar. Dalam rangka itu diperlukan program pelayanan yang seyogyanya merujuk pada keberadaan dan kebutuhan anak tunagrahita. Dengan demikian, fungsi pendidikan bagi anak tunagrahita dapat didudukkan sebagai upaya memaksimalkan potensi dalam upaya mengembangkan bakat dan kemampuan yang dimilikinya.

Permasalahan ini diangkat berdasarkan pengamatan di mana anak usia dini dengan kelainan tunagrahita ringan di kelas I belum memiliki kemampuan menulis dengan tangan atau menulis permulaan sesuai dengan yang diharapkan. Padahal kemampuan menulis dengan tangan atau menulis permulaan merupakan 
syarat mutlak bagi anak tunagrahita sebelum mereka memasuki kelas I dan kemampuan menulis sejak awal masuk sekolah dasar merupakan prasyarat bagi upaya belajar berbagai bidang studi yang lain. Sejak awal masuk sekolah anak harus belajar menulis karena kemampuan ini merupakan prasyarat bagi upaya belajar berbagi bidang studi lainnya (Abdurrahman, 2012). Bagi siswa tunagrahita, menulis merupakan suatu hal yang amat sulit dilakukan karena rendahnya inteligensi yang dialami oleh siswa tunagrahita. Mengamati gejala tersebut diperlukan upaya untuk mengungkap kesulitan-kesulitan yang dihadapi anak usia dini siswa dengan kelainan tunagrahita dalam menulis dan penyebab kesulitan tersebut. Dengan diketahuinya kesulitan dan penyebab kesulitan menulis, maka akan dapat dilakukan pengajaran yang tepat dengan menggunakan media pembejaran yang tepat pula sesuai dengan kemampuan yang dimiliki siswa dengan kelainan tunagrahita.

\section{Kemampuan menulis permulaan siswa tunagrahita ringan setelah diberikan perlakuan dengan menggunakan media huruf bergambar}

Setelah diberikan perlakuan dalam mengerjakan soal yang telah diberikan, hasil menulis siswa terlihar lebih baik dalam mengerjakan. Berdasarkan hasil analisis nilai posttest dapat diketahui bahwa terdapat 2 siswa dengan presentase $40 \%$ berada pada kategori sangat baik, 2 siswa dengan presentase $40 \%$ berada pada kategori baik, dan 1 siswa dengan presentasi $20 \%$ berada pada kategori cukup. Dari data tersebut menjelaskan nilai posttest lebih baik daripada nilai pretest.

Berdasarkan uraian di atas, dapat disimpulkan bahwa terdapat perbedaan nilai sebelum dan sesudah penggunaan media huruf bergambar. Maka dapat ditarik kesimpulan bahwa penggunaan media huruf bergambar berpengaruh signifikan terhadap kemampuan menulis permulaan siswa tunagrahita ringan kelas I SDLB BC Kepanjen Kabupaten Malang.

Pelaksanaan kegiatan penelitian ini dilakukan pada siswa tunagrahita ringan kelas 1 SDLB BC Kepanjen Kabupaten Malang yang berjumlah 5 siswa. Pada tahap ini siswa diberikan post-test sebanyak 4 kali. Dalam tahap post-test ini bertujuan untuk mengetahui prestasi dalam menelis permulaan siswa setelah diberikannya perlakuan dengan menggunakan media huruf bergambar.

Pada saat pemberian posttest terlihat banyak jawaban siswa yang sudah benar. Dalam menyebutkan huruf anak sudah dapat menyebutkan huruf dengan baik. Dalam hal menuliskan huruf siswa sudah mengalami peningkatan lebih baik meskipun ada beberapa siswa yang kurang tepat dalam menuliskan huruf dan masih sedikit mendapatkan bantuan. Siswa sudah bisa menuliskan huruf dengan baik meskipun siswa masih menirukan huruf.

Hamalik dalam Arsyad (2014:15) mengemukakan bahwa pemakaian media pembelajaran dalam proses belajar mengajar dapat membangkitkan keinginan dan minat yang baru, membangkitkan motivasi dan rangsangan kegiatan belajar, dan bahkan membawa pengaruh-pengaruh psikologis terhadap siswa. Pengaruh ada tidaknya media tersebut dapat dilihat dari nilai yang diperoleh selama posttest dengan menggunakan soal dengan bobot yang sama pada waktu pelaksanaan pretest. Kemampuan menulis permulaan siswa tunagrahita ringan kelas I SDLB BC Kepanjen Kabupaten Malang mendapatkan 
hasil yang lebih baik daripada sebelum diberikan perlakuan menggunakan media huruf bergambar.

Menurut Putri (2013:97) "Kesulitan yang dihadapi siswa tunagrahita dalam menulis adalah sulit memusatkan perhatian konsentrasi, daya ingat dan daya beda dalam mengingat huruf, kata, dan angka". Pada aspek menulis anak dituntut untuk bisa menulis dengan sikap yang benar (memegang dan menggunakan alat tulis, posisi kertas dan posisi badan dalam menulis), menebalkan dan menjiplak huruf/ kata, menyalin huruf/ kata serta melengkapi huruf yang hilang dalam sebuah kata. Dengan begitu penyajian yang paling efektif adalah dengan menggunakan media pembelajaran. Media yang digunakan dalam penelitian ini adalah media huruf bergambar yang berguna untuk kemampuan menulis permulaan pada siswa tunagrahita ringan yang menjadikan pembelajaran semakin menarik sehingga materi pembelajaran yang bersifat abstrak dapat disampaikan dengan bantuan media.

\section{Pengaruh penggunaan media huruf bergambar terhadap menulis permulaan siswa tunagrahita ringan kelas 1 SDLB BC Kepanjen Kab Malang}

Penggunaan media huruf bergambar berpengaruh terhadap kemampuan menulis permulaan siswa tunagrahita ringan kelas I SDLB BC Kepanjen Kepanjen Malang. Hal ini dapat buktikan dengan perbedaan rata-rata pretest 39 dan rata-rata posttest 72,75 . Berdasarkan hasil pengujian hipotesis menggunakan rumus Uji T Berpasangan (Paired Sample t-Test) menunjukkan nilai Sig. (2tailed) sebesar 0,01. Nilai sig 2 tailed $0,01<0,05$ jadi dapat disimpulkan ada pengaruh media huruf bergambar terhadap kemampuan siswa tunagrahita ringan kelas 1 SDLB BC Kepanjen Kabupaten Malang.

Media murupakan salah satu alat komunikasi yang digunakan dalam proses belajar dan pembelajaran untuk membawa informasi berupa materi ajar dari guru kepada murid sehingga murid menjadi lebih tertarik untuk mengikuti kegiatan pembelajaran. Pranata (2011:21) Media adalah bahan atau materi yang dituangkan ke dalam peralatan yang dapat menyimpan dan menyalurkan informasi atau kesan yang dikandungnya kepada penerima. Satu hal yang perlu diingat bahwa peranan media tidak akan efektif apabila penggunaanya tidak sejalan dengan isi dan tujuan pembelajaran yang telah dirumuskan. Secanggih apapun media tersebut tidak dapat dikatakan menunjang pembelajaran apabila keberadaanya menyimpang dari isi dan tujuan pembelajarannya.

Fungsi media menurut Kustiawan (2016:8), media pembelajaran merupakan alat bantu yang dapat mempermudah proses penerimaan materi pelajaran yang disampaikan dan sudah barang tentu akan mempermudah pencapaian keberhasilan tujuan pembelajaran. Hal ini dikarenakan siswa lebih termotivasi dalam mempelajari materi bahasan.

Media kartu adalah adalah kartu kecil yang berisi gambar, konsep, soal, atau tanda simbol yang mengingatkan atau menuntun anak kepada sesuatu yang berhubungan dengan materi yang sedang dipelajari. Kartu tersebut biasanya berukuran $8 \times 12 \mathrm{~cm}$ atau dapat disesuaikan dengan besar kecilnya yang dihadapi (Azhar Arsyad, 2014:19). Selain itu media kartu huruf juga dapat meminimalisir diskriminasi visual dan membantu ingatan visual anak tunagrahita. Levie \& Lentz dalam Arsyad (2014:9) menyimpulkan bahwa stimulus visual membuahkan hasil 
belajara yang baik untuk tugas-tugas seperti mengingat, mengenali, mengingat kembali, dan menghubungkan fakta dan konsep.

Disini peneliti memodifikasi media kartu huruf dengan media huruf bergambar berupa buku. Alasan peneliti memodifikasi media kartu huruf dengan media huruf bergambar berupa buku, supaya media huruf tersebut mudah dibawa kemana-mana dan tidak menyulitkan siswa tunagrahita untuk membawanya, selain itu mengurangi kekhawatiran kartu huruf tersebut hilang sebagian dikarenakan sudah terjilid menjadi 1 buku, siswa mudah tertarik, dan siswa mudah memahami.

Dalam menulis permulaan siswa tunagrahita ringan dengan menggunakan media huruf bergambar dapat meningkatkan kualitas belajar menulis permulaan karena proses belajar yang tidak membosankan. Siswa menjadi lebih aktif dalam kegiatan belajar menulis permulaan. Selain iu terlihat antusias yang cukup baik ketika siswa mendapatkan tugas untuk menulis dengan media huruf bergambar. Maka dari itu proses pembelajaran tersampaikan dengan baik.

\section{KESIMPULAN}

Berdasarkan analisis yang diuraikan pada bab sebelumnya, kesimpulan yang dapat diperoleh dari hasil penelitian. Pengaruh media huruf bergambar terhadap kemampuan menulis permulaan siswa tunagrahita kelas 1 SDLB BC Kepanjen Kab Malang. Kemampuan menulis permulaan siswa tunagrahita kelas 1 SDLB BC Kepanjen Kabupaten Malang sebelum menggunakan media huruf bergambar dikatakan sangat rendah. Dari hasil pre-test yang sudah dilakukan, kemampuan menulis permulaan siswa tunagrahita ringan memiliki nilai terendah 36,25 dan nilai tertinggi 45 dengan rata-rata 39,05 dengan kategori sangat rendah. Kemampuan menulis permulaan siswa tunagrahita ringan kelas 1 SDLB BC Kepanjen Kabupaten Malang sesudah menggunakan media huruf bergambar dikatakan menjadi lebih baik. Dari hasil post-test yang telah dilakukan, kemampuan siswa tunagrahita sesudah diberikannya media huruf bergambar memiliki nilai terendah 61,25 dan nilai tertinggi 88,75 dan memiliki rata-rata 72,75 denga kategori cukup. Berdasarkan uji hipotesis yang telah dilakukan, didapatkan hasil media huruf bergambar berpengaruh terhadap kemampuan menulis permulaan siswa tunagrahita ringan kelas 1 SDLB BC Kepanjen Kabupaten Malang.

\section{SARAN}

Bagi Kepala sekolah diharapkan dapat menjadikan hasil penelitian ini sebagai acuan untuk pengembangan pembelajaran di sekolah. Bagi guru perlu untuk menggunakan media huruf bergambar dalam pelaksanaan proses pembelajaran menulis permulaan untuk siswa tunagrahita ringan. Bagi peneliti selanjutnya, hendaknya mempersiapkan penelitian dengan lebih baik lagi, baik dari segi media huruf bergambar, materi, modifikasi pembelajaran maupun rencana pembelajaran.

\section{DAFTAR RUJUKAN}

Abdurrahman, Mulyono. 2012. Anak Berkesulitan Belajar Teori, Diagnosis, dan Remediasinya. Jakarta: PT Rineka Cipta 
Arsyad, A. 2014. Media Pembelajaran. Jakarta: PT RajaGrafindo Persada.

Chori, R. G. P., Sopandi, A. A., \& Azwandi, Y. 2013. Meningkatkan Kemampuan Menulis Permulaan Dengan Menggunakan Magic Whiteboard Bagi Anak Tunagrahita Sedang. E-JUPEKhu, (Online), 2(3), (http://ejournal.unp.ac.id/index.php/jupekhu/article/view/2109), diakses pada tanggal 14 juni 2017.

Jamaris, M. 2009. Kesulitan Belajar: Perspektif, Asessment dan Penanggulangannya. Jakarta: Yayasan Penamas Murni.

Kustiawan, Usep. 2016. Pengembangan Media Pembelajaran Anak Usia Dini. Malang: Penerbitan Gunung Samudra.

Mercer, C. D. \& Mercer, A.R. 1989. Teaching Students with Learning Problems. Ohio:Merril Publising Company. Pendidikan Tenaga Kependidikan dan Ketanagaan Perguruan Tinggi.

Pranata, S. A. 2011. Pengaruh Abjad 8 (ALPHABET 8S) dalam Mengatasi Kesulitan Menulis (Dysgraphia) dan Membaca (Dyslexia) Anak Tunagrahita Ringan. Doctoral diseertation, Universitas Sebelas Maret. (online), (http://eprints.uns.ac.id/5423/1/212351411201111341.pdf), diakses 26 April 2017

Putri, N. L. 2013. Kesulitan Menulis Permulaan pada Anak Usia Dini dengan Kelainan Tunagrahita Ringan. Jurnal Ilmu Pendidikan, 19(1), (online), (http://journal.um.ac.id/index.php/jip/article/view/3760), diakses 26 April 2017

Sugiono. 2015. Metode Penelitian Pendidikan. Bandung: Alfabeta. 